Guest Editorial, part of a Special Feature on Traditional Ecological Knowledge and Global Environmental Change

\title{
Traditional Ecological Knowledge and Global Environmental Change: Research findings and policy implications
}

\author{
Erik Gómez-Baggethun ${ }^{1,2}$, Esteve Corbera ${ }^{1,3}$ and Victoria Reyes-García ${ }^{4}$
}

\begin{abstract}
This paper introduces the special feature of Ecology and Society entitled "Traditional Ecological Knowledge and Global Environmental Change. The special feature addresses two main research themes. The first theme concerns the resilience of Traditional Ecological Knowledge (hereafter TEK) and the conditions that might explain its loss or persistence in the face of global change. The second theme relates to new findings regarding the way in which TEK strengthens community resilience to respond to the multiple stressors of global environmental change. Those themes are analyzed using case studies from Africa, Asia, America and Europe. Theoretical insights and empirical findings from the studies suggest that despite the generalized worldwide trend of TEK erosion, substantial pockets of TEK persist in both developing and developed countries. A common trend on the studies presented here is hybridization, where traditional knowledge, practices, and beliefs are merged with novel forms of knowledge and technologies to create new knowledge systems. The findings also reinforce previous hypotheses pointing at the importance of TEK systems as reservoirs of experiential knowledge that can provide important insights for the design of adaptation and mitigation strategies to cope with global environmental change. Based on the results from papers in this feature, we discuss policy directions that might help to promote maintenance and restoration of living TEK systems as sources of socialecological resilience.
\end{abstract}

Key Words: Adaptation, biocultural diversity, indigenous knowledge, resilience, small-scale societies

\section{INTRODUCTION}

Traditional Ecological Knowledge (hereafter TEK) consists of the body of knowledge, beliefs, traditions, practices, institutions, and worldviews developed and sustained by indigenous, peasant, and local communities in interaction with their biophysical environment (Toledo 2002, Berkes 2004). Disciplines from anthropology and ethnobiology to systems ecology and resilience theory have demonstrated the contribution of TEK to improving livelihoods (McDade et al. 2007, Reyes-García et al. 2008), sustaining biodiversity and ecosystems services (Gadgil et al. 1993, Reid et al. 2006), and building resilience in social-ecological systems (Folke 2004, Berkes and Davidson-Hunt 2006, Ceuretick et al. 2011, Gómez-Baggethun et al. 2012).

The potential contribution of TEK to building resilience in social-ecological systems has gained growing attention in the context of accelerated global change and generalized ecosystem service decline (MA 2005, Turnhout et al. 2012). Throughout history, communities maintaining tight links to ecosystem dynamics have developed knowledge, practices, and institutions to accommodate recurrent disturbances to secure their livelihood (Berkes et al. 2003). Because it coevolves with ecological and social systems, TEK can strengthen the capacity of human societies to deal with disturbances and to maintain ecosystem services and under conditions of uncertainty and change (Colding et al. 2003, Berkes and Turner 2006).
Since the advent of modernity, and most notably since the launch of the industrial revolution in Europe - expanded to other areas through the globalization process-, TEK has eroded in many parts of the world (Federici 2004, Maffi 2005, Toledo 2012). Erosion of TEK systems owes to complex and multifaceted reasons, including the compounding influences of formal schooling and loss of local languages (McCarter and Gavin 2011, Reyes-García 2013); dominant religions (Tang and Tang 2010); changes in land use (Kingsbury 2001, Gray et al. 2008); market integration (Godoy et al. 2005, ReyesGarcía et al. 2005); loss of access to resources through conservation programs (Gómez-Baggethun et al. 2010); mechanization of resource systems (Brodt 2001), and, more generally, industrialization and globalization processes (Turner and Turner 2008, Gómez-Baggethun 2009). The increase of the scale and pace of global change since the socalled "great acceleration" of the mid $20^{\text {th }}$ Century (Steffen et al. 2004) raised the question of whether TEK systems would adapt or disappear in the face of urbanization, technological development, and market globalization. Over the second half of the $20^{\text {th }}$ century decline in traditional lifestyles and associated knowledge was so widespread that when academia rediscovered TEK by the 1980s many doubted whether TEK systems would even survive the millennium (Cox 2000).

Over the last two decades however, major developments are reshaping societal perceptions regarding the fate of TEK. First, in recent years researchers are updating their perceptions of

\footnotetext{
${ }^{1}$ Institute of Environmental Science and Technology, Universitat Autònoma de Barcelona, Bellaterra, Barcelona, Spain, ${ }^{2}$ Social-Ecological Systems Laboratory, Department of Ecology, Universidad Autónoma de Madrid, Madrid, Spain, ${ }^{3}$ Department of Economics \& Economic History, Universitat Autònoma de Barcelona, Bellaterra, Barcelona, Spain, ${ }^{4}$ ICREA and Institute of Environmental Science and Technology, Universitat Autònoma de Barcelona, Bellaterra, Barcelona, Spain
} 
TEK's ability to adapt to change. Until recent TEK was largely perceived as a vestige of the past that held - at best - folkloric interest and was bound to disappear with economic development. Yet, recent research from developed and developing countries has found that substantial pockets of TEK persist in many rural and urban areas that have been subject to modernization processes (Godoy et al. 1998, Olsson and Folke 2001, Pieroni et al. 2004, Gómez-Baggethun et al. 2010, Calvet-Mir et al. 2011). Barthel et al. (2010) call pockets of social-ecologicalmemory those places that having captured, stored, and transmitted through time the knowledge and experience of managing a local ecosystem and the services it produces, continue to maintain and foster them despite drastic changes in the surrounding environments (see also Barthel and Isendahl 2013). For example, agricultural landscapes in Europe have evolved through thousands of years of interactions between social and ecological systems (Grove and Rackham 2001) and have drastically changed in the last century with societal transformation and industrialization of agriculture (Emanuelsson 2010). Yet many places still preserve local and traditional farming knowledge and techniques (Joffre et al. 1988, Beaufoy et al. 1994, Emanuelsson 2010).

Thus, the perception of TEK in the academy is shifting from one in which TEK was mainly perceived as existing in a rather essentialized and static form to one in which TEK is increasingly seen as having a hybrid and dynamic nature, more capable of adapting to new ecological and socioeconomic conditions than previously assumed. The dynamic nature of TEK is sometimes achieved through the accommodation of new forms of knowledge and by disregarding those knowledge components that become obsolete or less useful for daily life, provided that local people maintain the capacity to apply their knowledge (Gómez-Baggethun and Reyes-García 2013). For example, Eyssartier et al. (2011) document a case in Northwestern Patagonia, where local people maintain traditional practices on vegetable gardens but also adopt greenhouses, as those improve the conditions for certain crops. Though in a different domain of knowledge, Giovannini et al. (2011) document coexistence and complementarity of medicinal plants and pharmaceuticals knowledge among an indigenous population in Oaxaca, Mexico. Likewise many indigenous societies have retained animistic elements and worldviews merged with the religions to which they have been converted, and these worldviews keep affecting their activities and relations with their environments (Cook and Offit 2008, Frascaroli 2013).

Secondly, these new perspectives on the adaptive nature of TEK have favored an increasing recognition of the value of such knowledge in environmental policy (MA 2005, Reid et al. 2006, Turnout et al. 2012). International policy processes such as the United Nations' Declaration on the Rights of Indigenous Peoples and the Convention on Biological
Diversity have encouraged national governments to recognize and protect TEK for the conservation and sustainable use of biological diversity as well as to promote its wider application in resource management and biodiversity conservation (i.e., UNDRIP 2007, art. 31; CBD 1992, art. 8). This call has been taken up by national legislation of some countries that have started to develop national inventories of their TEK systems, acknowledging them as an important part of their cultural heritage (Pardo et al. 2012). Other major international initiatives for the protection of ecosystem services and biodiversity, such as the Millennium Ecosystem Assessment and The Economics of Ecosystems of Biodiversity, have also stressed the importance of traditional societies and associated knowledge and value systems for biodiversity protection (MA 2005, Raid et al. 2006, Brondizio et al. 2010). Also, the Intergovernmental Platform on Biodiversity \& Ecosystem Services (IPBES) has emphasized the importance of TEK in sustaining ecosystem services and biodiversity worldwide. It is thus expected that established and emerging policy recommendations will translate into the implementation of programs to sustain, protect, and restore TEK, as well as its associated lifestyles (Ruiz-Mallén et al. 2013).

Third, paralleling these trends, in some academic and civil society circles there is a mounting questioning of the technoscientific rationality and economic growth ideology of industrial Western civilizations (Feyerabend 1987, Hobart 1993, Noorgard 1994, Holling and Meffe 1996, Federici 2004, Latouche 2010, Toledo 2012). These trends go hand in hand with a seemingly revalorization of traditional lifestyles and associated knowledge systems and worldviews (Brondizio et al. 2010, Diamond 2012, Turnhout et al. 2012, Barnes et al. 2013, Wildcat 2013). Scholars concerned with TEK and other components of biocultural diversity have unearthed features of small-scale societies that had been downplayed by the societal imaginary of modernity. These features include: small-scale societies' capacity to harmonize livelihoods with biodiversity conservation (Gadgil et al. 1993, Turnhout 2012); adoption of reciprocity motives to drive their economies (Mauss 1954, Diamond 2012); working time limited by needs (Sahlins 1972); and capacity for collective action in governing common pool resources (Ostrom 1990). In essence, then, the status of TEK has been upgraded over the last two decades, not only in academia, but increasingly also among policymakers and civil society. Calls for the recognition of TEK are being slowly taken up by international treaties as an important potential contribution to the portfolio of responses to major social and environmental problems that humanity faces at present, including biodiversity loss, ecosystem service decline, and increased vulnerability and uncertainty associated with global environmental change (Berkes et al. 2000, McIntosh et al. 2000, Chapin et al. 2009, Diamond 2012, Turnhout 2012, Barnes et al. 2013). 


\section{INSIGHTS FROM THE SPECIAL FEATURE}

This special feature provides insights on two main research themes. The first concerns the conditions that might explain loss or persistence of TEK in the face of globalization, while the second theme relates to new findings regarding the way in which TEK systems enrich the resilience of social-ecological systems in responding to global environmental change. The ensemble explores both the potential and the limitations of TEK in confronting global change, and analyzes the evolution of TEK systems in response to environmental pressures and other socio-economic and cultural changes. The contributions also propose ways in which TEK can provide guidance on the design and implementation of policy programs that aim to increase the capacity of social-ecological systems to respond and to adapt to environmental and socio-economic stressors. Those themes are analyzed drawing on theoretical insights and empirical findings from case studies covering a broad range of societies and geographical contexts, including Asia (Indonesia), Africa (Kenya), South America (Bolivia), North America (Canada), and Europe (Spain, France, and Sweden), and related to a variety of ecosystems and resource systems, including forestry, fisheries, cattle ranging, agriculture, and horticulture.

The feature presents, first, an article by Ruiz-Mallén and Corbera (2013) who review the interactions between TEK and social-ecological resilience in the context of communitybased conservation in Latin America. Based on a review of 23 articles involving 29 case studies, the article shows that TEK can play a critical role in ensuring successful conservation outcomes in self-regulated initiatives but that it has less influence in contexts where scientific knowledge and formal state-driven sanctions may contribute more significantly to conservation. Based on the articles they reviewed, the authors conclude that there is a need to further investigate how climate variability and other global change stressors affect the joint evolution of TEK and conservation outcomes and to expand the common analytical focus on social resilience by paying broader attention to ecological dynamics and environmental change.

Boissiere and colleagues (2013) examine local perceptions of climate change in the tropical watershed of Mamberano, Papua, Indonesia. They show how perceptions of local communities on climate seasonality and meteorological events differ across villages and do not always match instrumentally measured meteorological records. The authors note that perceptual differences are explained not merely by the quality of meteorological records, but also by variations in TEK and local livelihoods, which have implications on people's cultural representation of climatic conditions. Subsequently, strategies to cope with climatic hazards particularly droughts and floods - also differ across villages and across gender and age groups. Some coping strategies are based on existing TEK, such as rituals or internal customary rules. Importantly, the study shows that meteorological hazards associated with climate change are perceived by the locals as having a modest impact on livelihoods when compared to other drivers of environmental change such as logging, mining, and infrastructure development projects that operate beyond their control. The authors conclude that policy design of adaptation strategies at the local level should focus on the stressors that local people judge most important and they suggest that TEK can provide practical insights for the design and promotion of these adaptation strategies.

Leclerc et al. (2013) analyze local perceptions of crop losses and associated causes - including extreme climate events over the past 40 years among Meru farmers in Kenya. The analysis suggests that local farmers hold fairly accurate knowledge and memory about the occurrence and intensity of drought and flooding-related events, especially those affecting crop yields. The authors conclude that this high level of accuracy in climate knowledge relates to the crossgenerational development of a local drought nomenclature among the Meru.

Boillat and Berkes (2013) examine how indigenous peoples near Cochabamba, Bolivia, ascribe meaning to global environmental change by means of their local belief systems. In line with Boissiere and colleagues, they examine cultural representations of environmental change, finding that local communities associate changes in climate to various stressors affecting their livelihoods and resource base, including population growth, out-migration, urbanization, and land degradation. The study also shows that cultural representations of change are contingent on locally-specific beliefs and other constitutive elements of community worldviews and note that environmental change among the studied communities is largely perceived as an integrative, all-encompassing and even cyclical process. In turn, the authors describe how local people track environmental changes by TEK-based observations and document local adaptation practices including adjustments in cultivation cycles, spreading risks of harvest failure through geographical dispersal of cultivated plots, buffering strategies sustained in social networks, and diversification of income sources, including off-farm employment. The authors claim that indigenous peoples should not be regarded as "helpless victims" of climate change but rather as active subjects that are able to build social-ecological resilience by developing multifaceted coping and adaptation strategies.

Turner and Spalding (2013) analyze ways in which TEK systems can contribute to interpretation, adaptation to, and buffering of global climate change among the First Nations of the Northwest Coast of Canada. They suggest that local capacity to respond to change stems largely from continued observation and monitoring of seasonal weather conditions, tides and currents, species and environmental indicators that contribute to a better understanding of the nature, rate and 
intensity of environmental changes. The authors argue that the TEK of First Nations people could be used to define a baseline of regional and local environmental conditions, and consistent with the recommendations by Boissiere and colleagues - suggest that this knowledge could inform the design of climate adaptation strategies at the local level. The authors also highlight the need to increase collaboration between indigenous peoples and modelers of climate and other environmental changes, in order to integrate TEK in modeling projections and scenario exercises. However, they also identify some barriers to realize these options, including a history of political and social marginalization, prejudicial treatment of indigenous peoples, and possible conflicts on intellectual property rights emerging from the potential integration of various types and sources of knowledge.

The article by Davidson-Hunt and colleagues (2013) documents and examines efforts among the Pikangikum (Anishinaabe) First Nation of north-western Ontario, Canada, to build a comanagement institution - a cooperative - for the collection and commercialization of nontimber forest products (NTFPs), based on the coproduction of knowledge involving Pikangikum and scientific partners. Insights from this article are highly relevant for the special feature insofar as they help us to reflect upon the need to create multistakeholder and indigenous-led partnerships and institutions that incorporate traditional knowledge to cope with environmental challenges and stressors. The authors show that Pikangikum peoples source their knowledge on forests dynamics and resources from culturally transmitted experience and TEK. Furthermore, they show that some individuals play a key role in the formation of new institutions for the coproduction of knowledge alongside scientific partners and the subsequent design and implementation of future ventures.

Barthel et al. (2013) explore links between TEK and resilience in European landscapes of food production, in what they call biocultural refugia. They focus on the carriers by which knowledge, experience and practice of managing a local ecosystem and its services are captured, stored, revived and transmitted through time as social memory (Barthel et al. 2010). They find that biodiversity of many cultural landscapes has been maintained through local management practices, developed in the context of the relation between local environmental fluctuations and production. The intimate connection of TEK to particular landscapes is manifested in the mosaic of habitats that allow species to flourish and adapt to change. They discuss the role of biocultural refugia for carrying TEK and show that smallholders play an essential role in promoting a portfolio of practices that can enhance resilience in the face of environmental change, fluctuating markets, and cascading energy, financial, or political crises. They suggest that nurturing biocultural refugia will improve possibilities for future generations to access the rich fund of experience with biodiversity and ecosystem functioning that is embedded in traditions and cultures. The note that memory carriers of TEK are threatened by processes of land-grabbing and by agricultural industrialization. In Europe's agricultural landscapes, loss of TEK and practices is resulting in an associated erosion of biodiversity and regulating ecosystem services. The authors conclude that nurturing biocultural diversity is a fundamental principle for a planetary stewardship that will be needed in the near future.

The last paper, by Oteros-Rozas et al. (2013), examines the role of TEK among pastoralists of the Conquense Drove Road, a major transhumant network in Spain, in building resilience to cope with global change. The authors analyze trends in TEK among transhumant people by examining differences in the level of knowledge across generations and social groups. Two main conclusions are derived from their study. First, the authors identify a rich body of knowledge, practices, and institutions to cope with environmental change, including strategies to anticipate changes and spread risks over space and time through mobility, resource pooling, diversification, selection, and forecasting. Second, they find an intergenerational decline in the levels of TEK among the studied transhumants and conclude that maintaining conditions for herd mobility on foot (increasingly constrained by fencing and regulatory restrictions on access to land) is essential to sustain the capacity of these communities to maintain transhumance and keep their capacity to developing, testing, and applying their TEK in response to environmental and socioeconomic stressors.

\section{CONCLUSIONS}

We derive three key insights and associated implications for environmental and policy agendas. First, research contributions compiled in this special feature show that despite generalized trends of worldwide TEK erosion, important biocultural 'refugia' of traditional knowledge still persist among local communities in both developing and developed country settings, suggesting that some TEK systems can be resilient to modernization. In contexts of strong interaction with market economies, modern technologies, and lifestyles, however, TEK systems endure only by adopting hybrid types through accommodating new forms of knowledge. If hybridization implies that some pieces of traditional knowledge are replaced by modern knowledge, the fact that specific TEK components are lost or kept by a society is not as important as whether the society retains the ability to generate, transform, transmit, and apply TEK (GómezBaggethun and Reyes-García 2013), that is the resilience of the TEK system. This is not to say that global change is to be conceived as a neutral process. Major drivers of change such as the advance of extraction frontiers into indigenous territories and the commodification of their resource systems are institutionalized processes shaped by profit motives and unequal power relations. Contesting these processes can be both legitimate and necessary strategies to secure the right of 
indigenous peoples to maintain, control, protect, and develop their traditional knowledge. Yet, any approach attempting to preserve TEK in fossilized forms is bound to fail. Recognition of the adaptive nature of TEK will be essential to understand where resides the capacity of traditional knowledge systems to evolve and adapt in the face of change.

Second, as an important component of the world's biocultural heritage, TEK systems are increasingly acknowledged for their contribution to sustaining biodiversity and ecosystem services, and to building resilience in the face of global change. Success in building community resilience often relates to adaptation strategies oriented to spread risk across space (mobility), time (storage and rationing), asset classes (diversification), and households or communities (sharing and pooling) (Agrawal 2008, Gómez-Baggethun et al. 2012, Reyes-García et al. 2013). One of the main venues through which TEK contributes to building resilience in socialecological systems is thus through the multiple ways it promotes biocultural diversity. Biocultural diversity stemming from the traditional knowledge, practices, and institutions developed by human societies over a millenary experience of dealing with disturbance represents a precious asset to cope with challenges of global environmental change. Indexes of biological and language diversity suggest that biocultural diversity is eroding at alarming rates (Maffi 2005, Harmon and Loh 2010). Because traditional knowledge develops from long term observation of local ecological dynamics and learning from crises and mistakes, once bodies of TEK are lost, their regeneration may be irreversible in the short and medium terms, which implies a loss of options to respond to disturbance and global change.

Third, the articles of this feature suggest that the manifestations of global environmental change that governmental and international bodies identify as the priority for the design of coping and adaptation strategies (namely climate variability and long term change) do not always match with what local communities identify as the most pressing issues. Stressors like water pollution from mining and oil drilling, and land use change from deforestation and infrastructure development are often perceived as threatening livelihoods in far more direct and immediate ways than climate change. Indigenous and small-scale societies often develop their own representations of global change manifestations, attuned to local notions of value and ecological dynamics, and local systems for representing, monitoring, and understanding environmental change are often consistent with findings from instrumentally measured data. Local representations of environmental change based on TEK are to be taken seriously by scientific entities and policy agencies concerned with the design and implementation of adaptation strategies to global change (Barnes et al. 2013, Wildcat 2013). As previous research has already suggested, combining scientific and traditional knowledge stands as a promising approach to design adaptation strategies that are both scientifically sound and attuned to local value systems and priorities.

Responses to this article can be read online at: http://www.ecologyandsociety.org/issues/responses. php/6288

\section{Acknowledgments:}

Preliminary versions of the papers collected in this Special Feature were presented at a special session of the 13th Congress of the International Society of Ethnobiology: Cultural diversity and biological diversity for sustainable development: Exploring the past to build up the future. Montpellier, France, 25-25 May 2012, entitled 'Traditional Ecological Knowledge and Resilience to Global Environmental Change', coordinated by the Special Feature editors. The guest editors are grateful to all involved authors and reviewers for their time and effort, and to our supporting projects and institutions, including: the EU-FP7 COMBIOSERVE project under grant agreement $n^{\circ} 282899$ (Corbera and ReyesGarcía); the ERC-FP7 LEK project under grant agreement no261971 (Reyes-García) and the Spanish Research, Development and Innovation Secretariat 'Ramón y Cajal' fellowship-RYC-2010-07183-(Corbera).

\section{LITERATURE CITED}

Agrawal, A., 2008. The role of local institutions in adaptation to climate change. Paper prepared for the Social Dimensions of Climate Change Workshop, Social Development Department, World Bank, Washington, DC, 5-6 March.

Barthel, S. C. Crumley, and U. Svedin. 2013. Bio-Cultural Refugia - Safeguarding Diversity of Practices for Food Security and Biodiversity. Global Environmental Change 23 (5):10.1016/j.gloenvcha.2013.05.001 http://dx.doi.org/10.1016/ j.gloenvcha.2013.05.001

Barthel, S., and C. Isendahl. 2013. Urban gardens, agriculture, and water management: Sources of resilience for long-term food security in cities. Ecological Economics 86:224-234. http://dx.doi.org/10.1016/j.ecolecon.2012.06.018

Barthel, S., C. L. Crumley, and U. Svedin. 2013. Biocultural refugia: combating the erosion of diversity in landscapes of food production. Ecology and Society 18(4): 71. http://dx.doi. org/10.5751/ES-06207-180471

Barthel, S., C. Folke, C., and J. Colding. 2010. Socialecological memory in urban gardens: Retaining the capacity for management of ecosystem services. Global Environmental Change 20:255-265. http://dx.doi.org/10.1016/j.

gloenvcha.2010.01.001 
Barnes, J., M. Dove, M. Lahsen, A. Mathews, P. McElwee, R. McIntosh, F. Moore, J. O'Reilly, B. Orlove, R. Puri, H. Weiss, and K. Yager. Contribution of anthropology to the study of climate change. Nature 3:541-544.

Beaufoy, G., D. Baldock, and J. Clark. 1994. The nature of farming: Low intensity farming systems in nine European countries. IEEP, London, United Kingdom.

Berkes, F. 2004. Traditional Ecological Knowledge in perspective. Pages 1-6 in J.T. Inglis editor. Traditional Ecological Knowledge: Concepts and Cases. International Program on Traditional Ecological Knowledge, Ottawa, Canada.

Berkes, F., and I. Davidson-Hunt. 2006. Biodiversity, traditional management systems, and cultural landscapes: Examples from the boreal forest of Canada. International Social Science Journal 58:35-47. http://dx.doi.org/10.1111/ j.1468-2451.2006.00605.x

Berkes, F., and N. J. Turner. 2006. Knowledge, learning and the evolution of conservation practice for social-ecological system resilience. Human Ecology 34:479-494.

Berkes, F., J. Colding, and C. Folke. 2003. Navigating SocialEcological Systems. Building Resilience for Complexity and Change. Cambridge University Press, Cambridge, United Kingdom. http://dx.doi.org/10.1017/CBO9780511541957

Berkes, F., J. Colding, and C. Folke. 2000. Rediscovery of traditional ecological knowledge as adaptive management. Ecological Applications 10:1251-1262. http://dx.doi. org/10.1890/1051-0761(2000)010[1251:ROTEKA]2.0.CO;2

Boillat, S., and F. Berkes. 2013. Perception and interpretation of climate change among Quechua farmers of Bolivia: indigenous knowledge as a resource for adaptive capacity. Ecology and Society 18(4): 21. http://dx.doi.org/10.5751/ ES-05894-180421

Boissière, M., B. Locatelli, D. Sheil, M. Padmanaba, and E. Sadjudin. 2013. Local perceptions of climate variability and change in tropical forests of Papua, Indonesia. Ecology and Society 18(4): 13. http://dx.doi.org/10.5751/ES-05822-180413

Brodt, S. B. 2001. A Systems Perspective on the Conservation and Erosion of Indigenous Agricultural Knowledge in Central India. Human Ecology 29:99-120. http://dx.doi.org/10.1023/ A:1007147806213

Brondizio, E. S., F. Gatzweiler, C. Zagrafos, and M. Kumar. 2010. Socio-cultural context of ecosystem and biodiversity valuation. Pages 150-181 in P. Kumar, editor. The Economics of Ecosystems and Biodiversity (TEEB). United Nations Environmental Programme and the European Commission. Earthscan Press, London, UK.

Calvet-Mir, L., M. Calvet-Mir, L. Vaque-Nunez, V. ReyesGarcía. 2011. Landraces in situ Conservation: A Case Study in High-Mountain Home Gardens in Vall Fosca, Catalan Pyrenees, Iberian Peninsula. Economic Botany 65:146-157. http://dx.doi.org/10.1007/s12231-011-9156-1

Chapin, F. S., S. R. Carpenter, G. P. Kofinas. C. Folke, N. Abel, W. C. Clark, P. Olsson, D. M. Stafford Smith, B. Walker, O. R. Young, F. Berkes, R. Biggs, J. M. Grove, R. L. Naylor, E. Pinkerton, W. Steffen, and F. J. Swanson, 2010. Ecosystem stewardship: Sustainability strategies for a rapidly changing planet. Trends in Ecology and Evolution 25:241-249. http:// dx.doi.org/10.1016/j.tree.2009.10.008

Ceuterick, M., I., Vandebroek, A. Pieroni. 2011. Resilience of Andean urban ethnobotanies: a comparison of medicinal plant use among Bolivian and Peruvian migrants in the United Kingdom and in their countries of origin. Journal of Ethnopharmacology 136:27-54. http://dx.doi.org/10.1016/j. jep.2011.03.038

Colding, J., T. Elmqvist, and P. Olsson. 2003. Living with disturbance: Building resilience in social-ecological systems. Pages 163-173 in F. Berkes, J. Colding, and C. Folke, editors, Navigating Social-Ecological Systems: Building Resilience for Complexity and Change. Cambridge University Press, Cambridge, UK. http://dx.doi.org/10.1017/CBO9780511541957.011

Cook, G., and T. Offit. 2008. Pluralism and transculturation in indigenous maya religion. Ethnoecology 47:45-59.

Cox, P. A. 2000. Will tribal knowledge survive the Millennium? Science 287:44-45. http://dx.doi.org/10.1126/ science.287.5450.44

Davidson-Hunt, I. J., C. J. Idrobo, R. D. Pengelly, and O. Sylvester. 2013. Anishinaabe adaptation to environmental change in northwestern Ontario: a case study in knowledge coproduction for nontimber forest products. Ecology and Society 18(4): 44. http://dx.doi.org/10.5751/ES-06001-180444

Diamond, J. 2012. The world until yesterday: What can we learn from traditional societies? Viking, New York, New York, USA.

Emanuelsson, U. 2010. The rural Landscapes of Europe: How man has shaped European nature. Formas (Swedish Research Council for Environment, Agricultural Sciences and Spatial Planning), Sweden.

Eyssartier, C., Ladio A. H. and M. Lozada. 2011. Traditional horticultural knowledge change in a rural population of the Patagonian steppe. Journal of Arid Environments 75:78-86. http://dx.doi.org/10.1016/j.jaridenv.2010.09.006

Federici, S. 2004. Caliban and the witch. Women, the body and primitive accumulation. Autonomedia. New York, New York, USA.

Feyerabend, P. 1987. Farewell to Reason. Verso, London, UK. 
Folke, C. 2004. Traditional knowledge in social-ecological systems. Ecology and Society 9(3): 7. [online] URL: http:// www.ecologyandsociety.org/vol9/iss3/art7/

Frascaroli, F. 2013. Catholicism and Conservation: The Potential of Sacred Natural Sites for Biodiversity Management in Central Italy. Human Ecology 41:587-601. http://dx.doi. org/10.1007/s10745-013-9598-4

Gadgil, M., F. Berkes, and C. Folke, C. 1993. Indigenous knowledge for biodiversity conservation. Ambio 22:151-156.

Giovannini, P., V. Reyes-García, A., Waldstein, and M. Heinrich. 2011. Do pharmaceuticals displace local knowledge and use of medicinal plants? Estimates from a cross-sectional study in a rural indigenous community, Mexico. Social Science \& Medicine 72:928-936. http://dx.doi.org/10.1016/j. socscimed.2011.01.007

Godoy, R., V. Reyes-García, E. Byron, W. Leonard, and V. Vadez. 2005. The effect of market economies on the wellbeing of indigenous peoples and on their use of renewable natural resources. Annual Review of Anthropology 34:121138. http://dx.doi.org/10.1146/annurev.anthro.34.081804.120412

Gómez-Baggethun, E., and V. Reyes-García. 2013. Reinterpreting change in traditional ecological knowledge. Human Ecology 41:643-647. http://dx.doi.org/10.1007/ s10745-013-9577-9

Gómez-Baggethun, E., V. Reyes-García, P. Olsson, and C. Montes. 2012. Traditional ecological knowledge and community resilience to environmental extremes. A case study in Doñana, SW Spain. Global Environmental Change 22:640-650. http://dx.doi.org/10.1016/j.gloenvcha.2012.02.005

Gómez-Baggethun, E., S. Mingorría, V. Reyes-García, L. Calvet, and C. Montes. 2010. Traditional ecological knowledge trends in the transition to a market economy: Empirical study in Doñana natural areas. Conservation Biology 24:721-729. http://dx.doi.org/10.1111/ j.1523-1739.2009.01401.x

Gómez-Baggethun, E. 2009. Perspectivas del conocimiento ecológico local ante el proceso de globalización. Papeles de relaciones ecosociales y cambio global 107:57-67.

Gray, C. L., R. E. Bilsborrow, J. L. Bremner, and F. Lu. 2008. Indigenous land use in the Ecuadorian Amazon: a crosscultural and multilevel analysis. Human Ecology 36:97-109. http://dx.doi.org/10.1007/s10745-007-9141-6

Grove, A. T., and O. Rackham. 2001. The nature of Mediterranean Europe: An ecological history. Yale University Press, London.

Harmon, D., and Loh, J. 2010. The Index of Linguistic Diversity: A New Quantitative Measure of Trends in the Status of the World's Languages. Language Documentation and Conservation 4:97-151.
Hobart, M. (editor) 1993. An Anthropological Critique of Development: The Growth of Ignorance. Routledge, New York, USA.

Holling, C. S., and, G. K. Meffe. 1996. Command and control and the pathology of natural resource management. Conservation Biology 10:328-337 http://dx.doi.org/10.1046/ j.1523-1739.1996.10020328.x

Joffre, R., J. Wacher, C. De los Llanos, and G. Long. 1988. The dehesa: An agrosilvopastoral system of the Mediterranean region with special reference to the Sierra Morena area of Spain. Agroforestry Systems 6:71-96.

Kingsbury, N. D. 2001. Impacts of land use and cultural change in a fragile environment: indigenous acculturation and deforestation in Kavanayen, Gran Sabana, Venezuela. Interciencia 26:327-336.

Latouche, S. 2010. Farewell to Growth. Polity Press.

Leclerc, C., C. Mwongera, P. Camberlin, and J. BoyardMicheau. 2013. Indigenous past climate knowledge as cultural built-in object and its accuracy. Ecology and Society 18(4): 22. http://dx.doi.org/10.5751/ES-05896-180422

Maffi, L. 2005. Linguistic, Cultural, and Biological Diversity. Annual Review of Anthropology 34:599-618. http://dx.doi. org/10.1146/annurev.anthro.34.081804.120437

Mauss, M. 1954. The gift. Free press, New York, USA.

McCarter, J., and M. C. Gavin. 2011. Perceptions of the value of traditional ecological knowledge to formal school curricula: opportunities and challenges from Malekula Island, Vanuatu. Journal of Ethnobiology and Ethnomedicine 7(38). http://dx. doi.org/10.1186/1746-4269-7-38

McDade, T., V. Reyes-García, W. Leonard, S. Tanner, and T. Huanca. 2007. Maternal ethnobotanical knowledge is associated with multiple measures of child health in the Bolivian Amazon. Proceedings of the National Academy of Sciences 104: 6134-6139.

McIntosh, R. J., Tainter, J. A., McIntosh, S. K., 2000. Climate, history and human action. Pages 1-42 in R. J. McIntosh, J. A. Tainter, and S. K. McIntosh, editors, The Way the Wind Blows: Climate, History, and Human Action. Columbia University Press, New York, USA.

Millennium Ecosystem Assessment (MA). 2005. Ecosystems and Human Well-Being: A Framework for Assessment. Island Press, Washington, D.C., USA.

Norgaard, R.B., 1994. Development Betrayed: the End of Progress and a Coevolutionary Revisioning of the Future. Routledge, New York, USA.

Olsson, P., and C. Folke. 2001. Local ecological knowledge and institutional dynamics for ecosystem management: a study 
of Lake RackenWatershed, Sweden. Ecosystems 4:85-104. http://dx.doi.org/10.1007/s100210000061

Oteros-Rozas, E., R. Ontillera-Sánchez, P. Sanosa, E. GómezBaggethun, V. Reyes-García, and J. A. González. 2013. Traditional ecological knowledge among transhumant pastoralists in Mediterranean Spain. Ecology and Society 18 (3): 33. http://dx.doi.org/10.5751/ES-05597-180333

Pardo de Santayana, M., R. Morales, L. Aceituno, M. Molina, and J. Tardío. 2012. El inventario español de los conocimientos tradicionales. Ambienta.

Pieroni, A., C. Quave, and R. Santoro. 2004. Folk pharmaceutical knowledge in the territory of Dolomiti Lucane, inland Southern Italy. Journal of Ethnopharmacology 95: 373-384. http://dx.doi.org/10.1016/j.jep.2004.08.012

Reid, W. V., F. Berkes, T. Wilbanks, and D. Capistriano, editors. 2006. Bridging scales and local knowledge in assessments. Island Press, Washington, D.C., USA

Reyes-García, V. 2013. Introduction to Special Section: On the relations between schooling and local knowledge. Guest Editorial. Learning and Individual Differences, 27:201-205. DOI: http://dx.doi.org/10.1016/j.lindif.2013.05.003 http://dx. doi.org/http://dx.doi.org/10.1016/j.lindif.2013.05.003

Reyes-García, V., M. Salpeteur, L. Calvet-Mir, T. Serrano, and E. Gómez-Baggethun. 2013a. Coupling technology with traditional knowledge and local institutions to help rural households to deal with change. Secheresse, in press.

Reyes-García, V., M. Gueze, A. C. Luz, M. Macia, M. OrtaMartínez, J. Paneque-Gálvez, J. Pino, X. Rubio-Campillo. $2013 b$. On the secular loss of traditional ecological knowledge. Estimates from the Bolivian Amazon. Evolution and Human Behavior 34:249-257.

Reyes-García, V., Mcdade, T., Vadez, V., Huanca, T., Leonard, W. R., Tanner, S., and R. Godoy. 2008. Non-market returns to traditional human capital: Nutritional status and traditional knowledge in a native Amazonian society. Journal of Development Studies, 44: 217-232. http://dx.doi. org/10.1080/00220380701789901

Ruiz-Mallén, I. and E. Corbera. 2013. Community-based conservation and traditional ecological knowledge: implications for social-ecological resilience. Ecology and Society 18(4):12. http://dx.doi.org/10.5751/ES-05867-180412

Ruiz-Mallén, I., Corbera, E., Novkovic, A., Calvo-Boyero, D., and Reyes-García, V. 2013. Adapting to environmental change in Latin America: Planning the future from the bottomup. Policy implications of COMBIOSERVE, an EU-funded research project on community-based conservation in Latin America. European Policy Brief, 2013.
Sahlins, M., 1972. Stone Age Economics. Tavistock, London, UK.

Steffen, W., A. Sanderson, P. D. Tyson, J. Jäger. P. A. Matson, B. Moore III, F. Oldfield, K. Richardson, H. J. Schellnhuber, B. L. Turner II, and R. J. Wasson. 2004. Global Change and the Earth System: A Planet Under Pressure. Springer-Verlag Berlin Heidelberg New York.

Tang, C.-P., and S.-Y. Tang. 2010. Institutional Adaptation and Community-Based Conservation of Natural Resources: The Cases of the Tao and Atayal in Taiwan. Human Ecology 38:101-111. http://dx.doi.org/10.1007/s10745-009-9292-8

Toledo, V. 2002. Ethnoecology: A conceptual framework for the study of indigenous knowledge of nature. Ethnobiology and Biocultural Diversity. International Society of Ethnobiology, Georgia, USA.

Toledo, V. 2012. Ten theses on the crisis of modernity. Polis 33. http://polis.revues.org/8544; DOI : 10.4000/polis.8544

Turner, N., and P. R. Spalding. 2013. "We might go back to this"; drawing on the past to meet the future in northwestern North American indigenous communities. Ecology and Society 18(4): 29. http://dx.doi.org/10.5751/ES-05981-180429

Turner N. J., and K. Turner. 2008. "Where our women used to get the food": Cumulative effects and loss of ethnobotanical knowledge and practice; case study from coastal British Columbia. Botany 86:103-115. http://dx.doi.org/10.1139/ B07-020

Turnhout, E., Bloomfield, B., Hulme, M., Vogel, J., and B. Wynne. 2012. Conservation policy: Listen to the voices of experience. Nature 488: 454-455. http://dx.doi.org/10.1038/488454a

Wildcat, D.R. 2013. Introduction: climate change and indigenous peoples of the USA. Climatic Change 120:509-515. http://dx.doi.org/10.1007/s10584-013-0849-6 